\title{
Policentryczność regionów miejskich w Polsce Polycentricity of urban regions in Poland
}

\author{
Bartosz Bartosiewicz (D) Szymon Marcińczak (D) \\ Uniwersytet Łódzki \\ Wydział Nauk Geograficznych \\ ul. Kopcińskiego 31, 90-142 Łódź \\ bartosz.bartosiewicz@geo.uni.lodz.pl•szymon.marcinczak@geo.uni.lodz.pl
}

\begin{abstract}
Zarys treści. Przedmiotem artykułu jest pomiar policentryczności regionów miejskich w Polsce oraz ilustracja zróżnicowania przestrzennego tego zjawiska. Badanie zostało przeprowadzone na podstawie danych na temat rozmieszczenia miejsc pracy (policentryczność morfologiczna) oraz dojazdów do pracy (policentryczność funkcjonalna). Badanie właściwe poprzedza wyjaśnienie pojęcia policentryczności, które w literaturze przedmiotu nie jest jednoznaczne. Pomiar policentryczności prowadzony jest na zbiorze autorskich regionów miejskich, delimitowanych zgodnie z koncepcją dziennych systemów miejskich (daily urban systems). W artykule policentryczność mierzona jest metodą zaproponowaną przez Burgera (2011) - tzw. prymatem policentryczności. Dodatkowo wyznaczane są typy policentryczności według typologii van der Laana (1998). Otrzymane wyniki wskazują, że w regionach miejskich w Polsce występuje silna zależność pomiędzy policentrycznością morfologiczną i funkcjonalną oraz że przeciętnie regiony miejskie są bardziej policentryczne funkcjonalnie niż morfologicznie.
\end{abstract}

Słowa kluczowe: policentryczność, regiony miejskie w Polsce, dojazdy do pracy.

Keywords: polycentricity, urban regions, Poland, commuting.

\section{Wstęp}

Pomimo znacznego dorobku literatury oraz wieloletniego zainteresowania problematyką policentryczności, jak zauważa Meijers (2008a), brakuje ogólnie przyjętych i stosowanych definicji pojęcia oraz sposobów mierzenia zjawiska policentryczności. Tradycyjnie, w literaturze z zakresu geografii miast oraz geografii osadnictwa, policentryczność regionu (najczęściej miejskiego) rozumiana jest jako wieloośrodkowość i utożsamiana z pojęciem konurbacji (Szajnowska-Wysocka, 1995). Klasycznym przykładem układu policentrycznego w Polsce jest Górny Śląsk, składający się z wielu ośrodków (miast, centrów) o podobnej wielkości i znaczeniu w sieci osadniczej regionu. Przeciwieństwem takiej struktury są układy monocentryczne (jednoośrodkowe), gdzie występuje jedno dominujące miasto, w którym koncentruje się większość ludności i aktywności gospodarczej. Taki układ utożsamia się z pojęciem aglomeracji. Dobrym tego przykładem jest region stołeczny.

Takie rozumienie złożonych układów osadniczych (aglomeracja i konurbacja) w ostatnich kilkudziesięciu lat ewoluowało. Po pierwsze dzieje się to w skutek zmiany podejścia do definiowania i delimitowania regionu miejskiego. Region miejski przestaje być jedynie 
strukturą wyodrębnianą i opisywaną na podstawie cech zagospodarowania, rozmieszczenia ludności, miejsc pracy czy aktywności gospodarczej (Leszczycki et al., 1971). Upowszechnia się podejście funkcjonalne, które opisuje regiony miejskie poprzez związki, relacje, powiązania funkcjonalne występujące pomiędzy poszczególnymi centrami tego regionu (przykładowo w badaniach metropolitalnych) (Kurek et al., 2020; Śleszyński, 2013; Kociuba, 2015). Po drugie od kilku dekad regiony miejskie (w różnej w skali i dynamice) przechodzą przemiany związane z procesami takimi jak: suburbanizacja, dezurbanizacja oraz kontrurbanizacja. Pomiędzy poszczególnymi miastami/wsiami w regionach kształtują się skomplikowane powiązania oraz przepływy dóbr, towarów czy usług. Regiony miejskie stają się coraz bardziej złożone i coraz trudniej jest zachodzące w nich procesy wyjaśnić w ujęciu klasycznym. Często przestają być prostymi układami jednoośrodkowymi, jednocześnie nie przypominają klasycznych układów wieloośrodkowych. To komplikuje identyfikację ich struktury przestrzennej. Wymaga to innego spojrzenia na opisywanie i klasyfikacje tych struktur, wyodrębniania ich typów, ilustracji dynamiki zmian oraz ich zróżnicowania czy identyfikacji przyczyn tych procesów. Wśród różnych sposobów badania tego zjawiska istotne miejsce zajmuje koncepcja policentrycznego regionu miejskiego (PRM) czy policentrycznego rozwoju regionu miejskiego (por. Kloosterman i Musterd, 2001).

Policentryczność to pojęcie wieloznaczne i nie ma jednej uniwersalnej definicji tego zjawiska (Waterhout, 2002; Davoudi, 2003; Faludi, 2006). Można jednakże wyróżnić dwa główne podejścia definicyjne. Pierwsze, morfologiczne, gdzie policentryczność odnosi się do poziomu koncentracji różnych zjawisk przestrzennych oraz funkcjonalne, które dotyczy różnego rodzaju powiązań występujących pomiędzy miastem i jego otoczeniem w regionie miejskim (Rauhut, 2017). Równolegle policentryczność jest rozumiana jako termin polityczny, funkcjonujący przede wszystkim w dokumentach UE jako pożądany, modelowy stan rozwoju regionalnego/przestrzennego (CEC, 1999).

Przedmiotem artykułu jest opisana powyżej policentryczność regionów miejskich w Polsce, rozumianych za Scottem (1988) jako zamknięte układy osadnicze obejmujące skupiska miejsc pracy i zamieszkania wykazujące się silnymi codziennymi powiązaniami w zgodzie z formułą daily urban system (szerzej o wybranych do badania regionach miejskich w dalszej części tekstu). Celem głównym jest pomiar poziomu policentryczności morfologicznej i funkcjonalnej regionów miejskich w Polsce wraz ze wskazaniem jego zróżnicowania. Cel ten jest odpowiedzią na lukę w badaniach nad poziomem policentryczności w krajach Europy Środkowo-Wschodniej, które poprzez swoją historię oraz odmienny charakter organizacji przestrzeni odbiegają od sytuacji obserwowanej w Europie Zachodniej. Na tym tle bardzo dobrym przykładem jest Polska, cechująca się dużo niższym poziomem urbanizacji i odmienną strukturą przestrzenną sieci osadniczej niż kraje Europy Zachodniej.

W pierwszej części artykułu przedstawiano przegląd literatury przedmiotu. W kolejnej omówiono metody badawcze, materiały źródłowe i zdefiniowano obszar badań. Następna część pracy prezentuje wyniki badania policentryczności funkcjonalnej i morfologicznej regionów miejskich w Polsce oraz jej zróżnicowanie. Pracę wieńczą wnioski oraz dyskusja. 


\section{Nurty badań nad policentrycznością}

Policentryczność nie jest jedynie pojęciem tożsamym z wieloośrodkowym regionem miejskim, a przede wszystkim podejściem pozwalającym mierzyć strukturę przestrzenną regionu i jej zmiany. W myśl tego podejścia regiony mogą przyjmować formy od skrajnie monocentrycznych, czyli takich gdzie występuje jeden ośrodek centralny koncentrujący wszelką aktywność człowieka, po skrajnie policentryczne, w których aktywność ta jest rozłożona równomiernie pomiędzy poszczególne jego centra. Tak rozumiana policentryczność może być badana w ujęciu morfologicznym (odnoszącym się do rozmieszczenia pomiędzy centrami regionu miejskiego określonej aktywności człowieka - np. miejsc pracy) oraz funkcjonalnym (odnoszącym się do kierunków i wielkości powiązań pomiędzy centrami regionu miejskiego - np. dojazdów do pracy) (ryc. 1). W myśl tej koncepcji regiony miejskie mogą przyjmować różne typy i stadia rozwoju policentrycznego (ryc. 2). Takie badanie policentryczności jest relatywnie nowe, a w odróżnieniu od innych metod pozwala w sposób obiektywny, z zastosowaniem prostego zestawu narzędzi badawczych zmierzyć szereg cech regionu miejskiego.

Prezentowane podejście badawcze rozwinęło się na kanwie studiów nad policentrycznymi układami miejskimi (polycentric urban region), prowadzonych przede wszystkim w odniesieniu do regionów miejskich w Europie Zachodniej (Randstadt w Holandii, Zagłębie Ruhry w Niemczech, Flamisch Diamond w Belgii, Wielkiego Londynu w Wielkiej Brytanii) (por. Burger i Meijers, 2012; Burger et al., 2011; de Goei et al., 2010; Boussauw et al., 2011; Growe, 2012; Taubenböck et al., 2017). Następnie podejście to zostało adaptowane przez badaczy chińskich do studiów nad tamtejszymi regionami miejskimi i tam obecnie jest najbardziej rozwijane (Lin et al., 2015; Liu i Wang 2016; Deng et al., 2019; Zhang i Derudder, 2019). W ramach tych studiów powstało wiele podejść do pomiaru zjawiska policentryczności. Można je podzielić na trzy główne grupy. Pierwsza grupa wzoruje się na metodzie rozkładu wielkości rang (rank-sized distribution) (Burger i Meijers, 2012). Miary w tej grupie bazują na regule Zipfa (1949). Druga grupa opiera się metodach według teorii sieci społecznych. W tym nurcie pomiarów dokonują m.in. Green $(2007,2008)$ oraz Liu et. al. (2016), Burger et al. (2011), van der Laan et al. (1998) czy Limtanakool et al. (2007, 2009). Trzecia grupa metod obejmuje miary policentryczności bazujące na jej porównywaniu do idealnego modelu policentryczności (Vasanen, 2012; Hanssens et al., 2014; Deng et al., 2019 czy Shu et al., 2019). Ostatnia z grup odnosi się do konkretnych przykładów i metody nie są użyteczne w studiach porównawczych.

Pomiar policentryczności prowadzony jest najczęściej w oparciu o informacje na temat wielkości oraz kierunków dojazdów do pracy. Ze względu na dostępność danych rzadziej stosuje się inne sposoby pomiaru zjawiska, choć przykładowo Burger i Meijers (2012) w swoich badaniach stosują oprócz dojazdów do pracy także dojazdy do placówek handlowych. Limtaankool et al. (2007, 2009), w zależności od skali prowadzonych badań, wykorzystują w tym celu zarówno dojazdy do pracy, jak i inne formy aktywności przestrzennej: dojazdy do usług czy wyjazdy wakacyjne. Za to Vassanen (2012) wykorzystuje dane na temat populacji, a Kloosterman i Lambregts (2001) w swoich rozważaniach rozpatrują strukturę przestrzenną przedsiębiorstw typu start up.

Policentryczność jest rozpatrywana w trzech różnych skalach: wewnątrzmiejskiej, regionu miejskiego oraz regionalnej, a nawet ponadregionalnej (Rauhut, 2017). W przy- 


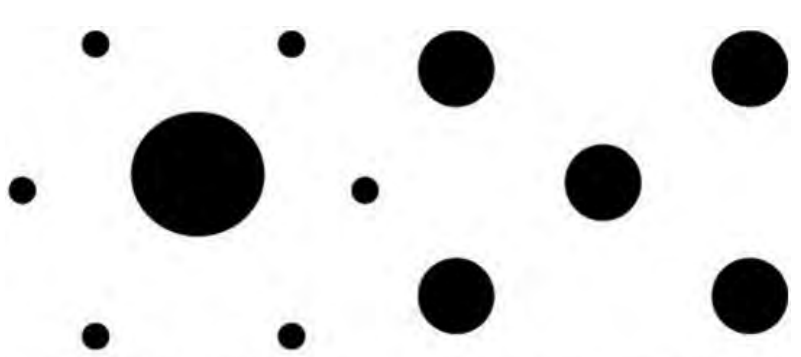

Region monocentryczny funkcjonalnie

Region policentryczny funkcjonalnie

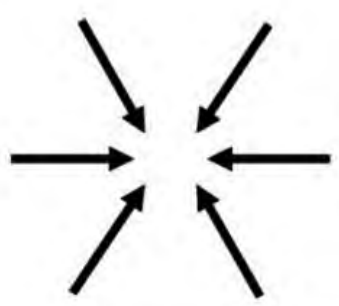

Region monocentryczny morfologicznie

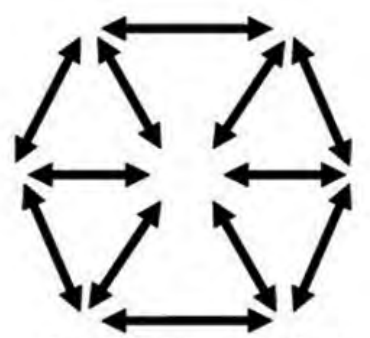

Region policentryczny morfologicznie

Ryc. 1. Policentryczność morfologiczna i funkcjonalna Morphological and functional polycentricity Źródło: Burger et al. (2011, s. 4).

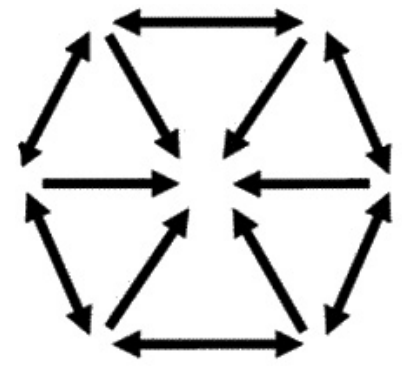

Policentryczny $z$ dużym udziałem zwrotnych relacji z pominięciem miasta centralnego
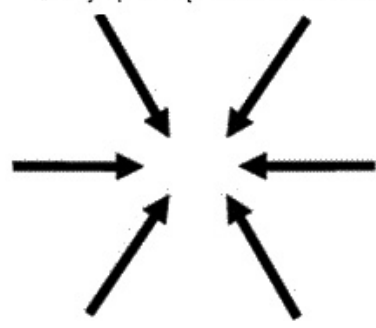

Monocentryczny

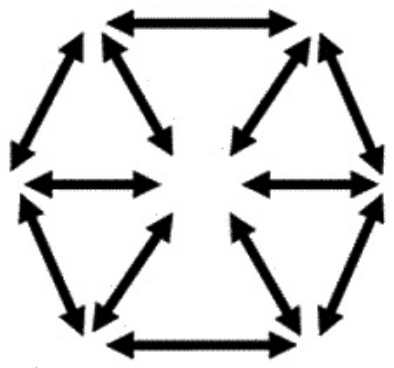

Policentryczny zdecentralizowany
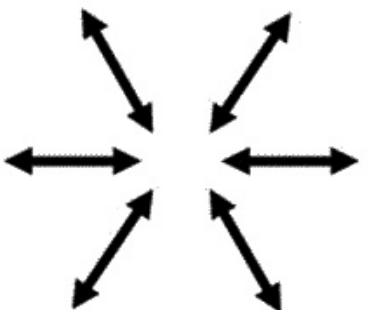

Policentryczny z pr zewagą relacji zwrotnych

Ryc. 2. Typy policentryczności funkcjonalnej regionów miejskich ( $w$ wersji angielskiej są to następujące typy: polycentric criss-cross, polycentric decentralized, monocentric, polycentric exchange) Types of functional polycentricity of urban regions (polycentric criss-cross, polycentric decentralised, monocentric, polycentric exchange)

Źródło: Burger et al. (2011, s. 4). 
padku skali wewnątrzmiejskiej, szukając początków badań nad policentrycznością, można odnosić się już do Chicagowskiej Szkoły Socjologicznej, która miała największy wpływ na kształtowanie miast, przede wszystkim amerykańskich, do lat 60. XX w. Wzorcem było miasto amerykańskie o monocentrycznej strukturze z koncentracją aktywności w jednym głównym centrum (gdzie zlokalizowana jest całość miejsc pracy), w którym wraz ze wzrostem odległości od rdzenia gęstość aktywności maleje (Alonso, 1964). Od lat 40. XX w. zaczęto dostrzegać, że rozwój aktywności występuje nie tylko w jednym rdzeniu (Harris i Ullman, 1945), ale do końca lat 60. XX w. policentryczność istniała tylko jako pojęcie, a nie narzędzie opisu zjawisk w strukturze przestrzennej miasta (Kloosterman i Musterd, 2001). Od lat 70. XX w. policentryczność stała się na tyle widoczna, że stało się jasne, że jest to model, który wyjaśnia wzorce przemian struktury miasta. Regiony miejskie przestają być węzłowe, a ich rozwój jest wielordzeniowy - policentryczny (Thomas, 1973). W kolejnych latach następuje zmiana rozumienia procesów zachodzących w miastach i ich aglomeracjach. Rodzą się nurty badań w ramach ekonomiki aglomeracji (the economics of agglomeration) i klastrów aktywności (clusters of acitivity) (Scott, 1988; Porter, 1990; Krugman, 1993).

W skali regionu miejskiego (ta skala jest przedmiotem badania w artykule) policentryczność została dostrzeżona jeszcze wcześniej. Geddes (1915) używa pojęcia policentryczność jako synonimu konurbacji, a Fawcett (1932) i następnie Wurster (1963) - identyfikując polycentric urban region (PUR). Od lat 70. XX w. rośnie zainteresowanie badaczy relacjami występującymi pomiędzy miastami/jednostkami w obrębie regionów miejskich (Davoudi, 2003). Najpóźniej w badaniach nad policentrycznością zaistniała skala regionalna, której rozwój wiąże się z rozumieniem tego zjawiska jako narzędzia rozwoju regionalnego. Jest to tożsame z koncepcją rozwoju wprowadzoną do polityki UE w ramach ESDP (1999) (Faludi, 2006).

Policentryczność i jej zmiany mierzone są w różnych skalach. Najczęściej spotykane są badania porównawcze pomiędzy regionami miejskimi w krajach Europy Zachodniej, USA albo Azji. Takie analizy prowadzone są w ujęciu międzynarodowym - w tym nurcie swoje rozważania prowadzą m.in. Hall i Pain (2006); Limtanakool et al. (2007); Meijers (2008); Meijers et al. (2017). Równie liczne są badania prowadzone w skali regionalnej czy metropolitalnej (Sohn, 2005; de Goei et al., 2010; Burgalassi, 2010; Veneri, 2010; Vasanen, 2012). W tej skali analizy autorzy mierzą nie tylko regionalny poziom policentryczności, ale tak jak ma to miejsce np. u Burgalassiego (2010), analizują także wewnętrzną strukturę osadniczą regionu i jej wpływ na poziom policentryczności. W szczególności w ostatnich latach popularne stają się również pomiary prowadzone w skali wewnątrzmiejskiej. Ciekawe jest zarówno rozpatrywanie stopnia policentryczności morfologicznej czy funkcjonalnej w tej skali, jak i próba wyjaśniania zjawiska takimi cechami jak np. ukształtowanie terenu (Liu i Wang, 2016; Liu et al., 2017).

O ile studia nad poziomem policentryczności regionów miejskich są popularne w różnych częściach świata, to w przypadku Europy Środkowo-Wschodniej jest ich niewiele. Pojedyncze analizy odnoszą się do przykładów z: Węgier (Szabo et al., 2014), Czech (Malý, 2016) czy Estonii (Tammaru, 2005). W Polsce, wśród badań podejmujących ten wątek choćby pośrednio, można wymienić prace: Blazego (2008), Rosika et al. (2010), Bańskiego et al. (2012), Komornickiego et al. (2012, 2013) oraz Wiśniewskiego (2012). W Polsce szerzej badany jest wątek ponadregionalny, czyli policentryczności systemu osadniczego kraju jako całości. Na tym nurcie swoje rozważania koncentrują m.in. Korcelli (2004, 
2005a, 2005b) czy Śleszyński (2018). Popularne są również badania nad konurbacją śląską (w skali regionu miejskiego), która jest typowym układem policentrycznym w Polsce (Spórna, 2016; Krzysztofik et al., 2016; Zuzańska-Żyśko, 2018). Brakuje w Polsce prac ujmujących problematykę policentryczności w odniesieniu do regionów miejskich w ujęciu całościowym (dla całego kraju). Nie brakuje za to prac badających relacje (powiązania) funkcjonalne w regionach miejskich i to w różnych skalach oraz ujęciach, przede wszystkim tych metropolitalnych (m.in. Gorzelak i Smętkowski, 2005; Korcelli-Olejniczak, 2004; Markowski i Marszał, 2002, 2005; Śleszyński, 2013, 2015; Heffner i Gibas, 2017; Mikuła i Kaczmarek, 2017; Marszał, 2017), ale żadne z nich nie przenoszą swoich rozważań na problematykę policentryczności.

Klasycznie pomiar policentryczności odnosił się do morfologii danego obszaru i bazował na badaniu rozmieszczenia przede wszystkim ludności, ale także miejsc pracy. Współcześnie bardziej powszechne są badania dotyczącej policentryczności funkcjonalnej, albo te zintegrowane, odnoszące się do jej obu wymiarów. Ze studiów europejskich, bliskich Polsce ze względu na ogół procesów społeczno-gospodarczych, wyciągnąć można trzy główne wnioski. Po pierwsze obserwuje się wzrost policentryczności morfologicznej i funkcjonalnej w regionach miejskich Europy, co jest wynikiem dekoncentracji miejsc zamieszkania, jak i aktywności gospodarczej człowieka (Burger et al., 2011). Trend ten wpisuje się również w założenia polityki UE wobec regionów miejskich, która ideę rozwoju policentryczności wprowadziła i ją propaguje. Po drugie regiony miejskie w Europie wykazują się dużą zbieżnością pomiędzy poziomem policentryczności morfologicznej i funkcjonalnej. Świadczą o tym choćby badania regionów miejskich w Holandii czy Wielkiej Brytanii (Burger i Meijers, 2012). Ta zależność nie jest już wyraźna w przypadku regionów miejskich w Azji. Przykładowo w Chinach regiony te pozostają monocentryczne funkcjonalnie przy dużo wyższym poziomie policentryczności morfologicznej (Liu et al., 2016). Po trzecie policentryczność jest powszechnie stosowana na potrzeby wyjaśniania zróżnicowania różnych zjawisk: poziomu rozwoju regionalnego (Malý, 2016), zachowań transportowych (Camagni et al., 2002) czy wielkości emisji $\mathrm{CO}_{2}$ do atmosfery (Cirilli i Veneri, 2014).

\section{Organizacja badania}

\section{Metody pomiaru policentryczności}

W ostatnich 15 latach w literaturze europejskiej można odnotować co najmniej kilka podejść do pomiaru policentryczności regionów miejskich. Istotną inspiracją w tym zakresie były badania regionów miejskich w Europie prowadzonych w ramach sieci ESPON (ESPON 1.1.1, 2004 oraz ESPON 1.4.3, 2007). Jak wspomniano we wprowadzeniu, istnieją trzy główne grupy miar badających policentryczność. W artykule skorzystano z dwóch metod z nurtu miar według teorii sieci społecznych. Wybór akurat tych dwóch metod wynika przede wszystkim z prostoty ich konstrukcji oraz łatwości interpretacji wyników. A ich dobór poprzedzony jest szczegółowym przeglądem i oceną sześciu miar najczęściej wykorzystywanych w literaturze ${ }^{1}$.

\footnotetext{
${ }^{1}$ Oprócz omówionych metod są to (w oryginalnym brzmieniu): rank-sized distribution of nodality and centrality indexes (Burger i Meijers, 2012), general functional and morphological indexes (w dwóch odmianach: pierwszej autorstwa Greena, 2007 i drugiej autorstwa Liu et al., 2017), entropy index (Limtanakool et al., 2007).
} 
Pierwsza z zastosowanych metod to klasyczna miara policentryczności regionów miejskich, która została zastosowana dla Holandii przez van der Laana (1998) i bazuje na analizie wewnątrzregionalnych dojazdów do pracy. Polega ona na porównaniu pomiędzy sobą udziału dojazdów do pracy do miasta głównego w regionie miejskim w sumie obustronnych relacji pomiędzy miastem głównym a otoczeniem (tzw. exchange commuting index) oraz udziału dojazdów z pominięciem miasta głównego w ogóle relacji obserwowanych z jednostek wchodzących w skład regionu miejskiego (z wyłączeniem miasta głównego) (tzw. criss commuting index). W swoim badaniu van der Laan uwzględnia jedynie dojazdy do pracy obserwowane wewnątrz regionów miejskich. Wartości i relacje pomiędzy dwoma analizowanymi wskaźnikami decydują następnie o klasyfikacji regionów miejskich do jednego z czterech typów policentryczności: monocentric, criss cross, decentralized i exchange (por. ryc. 2). W swojej metodzie dodatkowo autor mierzy otwartość regionu miejskiego rozumianą jako wielkość dojazdów z/do danego regionu miejskiego do/z regionów sąsiednich. Nie uwzględnia ich jednakże w pomiarze policentryczności. Do zalet metody należy jej prostota i łatwość w liczeniu. Autor metody przyjmuje, że regiony z założenia są monocentryczne, co jest niewątpliwą jej wadą. W trakcie pomiaru należy się zdecydować, które miasto jest główne w regionie miejskim i prowadzić obliczenia opierając się na jego relacjach z otoczeniem. W podobny sposób jak van der Laan do badania policentryczności podchodzą Burger et al. (2011) w rozważaniach nad relacją pomiędzy policentrycznością funkcjonalną i morfologiczną regionów miejskich w Anglii i Walii oraz ich zmianą w latach 1981-2001. Autor oblicza prymat funkcjonalny (functional primacy) regionu miejskiego jako udział dojazdów do miasta głównego w ogóle dojazdów obserwowanych w regionie miejskim. Im wyższy, tym większa monocentryczność funkcjonalna (wartości miernika mieszczą się w przedziale 0-1). A także oblicza prymat morfologiczny (morphological primacy) jako udział pracujących w mieście głównym do ogółu pracujących w regionie miejskim. Im wyższa wartość wskaźnika tym wyższa monocentryczność morfologiczna (wartości miernika mieszczą się w przedziale 0-1). Dodatkowo wyznacza jeszcze dwie miary pomocnicze: gęstość sieci (network density - ND) jako udział dojeżdżających do pracy w obrębie regionu miejskiego w ogóle pracujących w regionie miejskim² i otwartość regionu miejskiego (outward openness - 00), która określa udział dojazdów na zewnątrz regionu miejskiego w ogóle pracujących w regionie miejskim.

W przypadku obu wskaźników policentryczności funkcjonalnej mierzy się jedynie zjawiska obserwowane wewnątrz regionów miejskich. Pomija się powiązania (relacje) zachodzące pomiędzy danym regionem miejskim i jego zewnętrznym otoczeniem.

\section{Obszar badań}

Badanie policentryczności prowadzone jest na zbiorze 56 autorskich regionów miejskich. Procedura ich wyznaczania okazała się zdaniem autorów niezbędna, gdyż w odróżnieniu od wielu krajów europejskich (np. Holandia - por. van der Laan, 1998; Burger et al., 2011 czy Anglia - por. Melo et al., 2012) brak jest jednej kompleksowej delimitacji tego rodzaju w Polsce.

${ }^{2}$ Wskaźnik gęstości sieci ilustruje odsetek dojeżdżających do pracy (poza granice gminy miejsca zamieszkania) w odniesieniu do ogółu pracujących w regionie (dotyczy dojazdów w obrębie regionu miejskiego). Jego wartości będą niskie, kiedy większość osób pracuje w gminie swojego zamieszkania i rośnie wraz ze wzrostem dojazdów. Im większa wartość wskaźnika, z tym większą mamy do czynienia skalą przepływów do pracy. 
Delimitacja regionów miejskich w Polsce ma długą tradycję. W sposób kompleksowy przeglądu tych podejść dokonuje w swojej pracy Śleszyński (2015), pokazując zarówno podejścia klasyczne z perspektywy czasu (Potrykowska, 1989), jak i te współczesne (Śleszyński, 2014). Istnieje szereg innych podejść delimitacyjnych, również takich w skali regionalnej (np. Heffner i Gibas, 2015 czy Bartosiewicz, 2016). Delimitacje te albo nie biorą pod uwagę faktycznych przepływów i przyjmują a priori założenie, że regiony są monocentryczne - biorą pod uwagę jedynie powiązania z miastem centralnym (Śleszyński, 2013; Korcelli i Śleszyński, 2008), albo przyjęta procedura ich delimitacji prowadzi do wyznaczenia dużej oraz bardzo zróżnicowanej pod względem wielkości liczby lokalnych rynków pracy - odpowiedników regionów miejskich (Gruchociak, 2012). Wadą większości tych podejść jest założenie o istnieniu miasta głównego. Wszystkie w ten sposób zakładają określenie de facto zasięgu wpływu/oddziaływania miasta. Kompleksową delimitację regionów miejskich wykonano w ramach programu URBAN AUDIT będącej inicjatywą Komisji Europejskiej i Eurostatu, a wykonaną przez GUS. Jej wyniki pod względem liczby wyznaczonych regionów są podobne do zaprezentowanej poniżej, ale w co najmniej kilku przypadkach są kontrowersyjne. Dobrym przykładem jest region tódzki, w którym rozdzielono obszar funkcjonalny Łodzi i Pabianic, które w rzeczywistości tworzą jeden spójny region.

Warto również zauważyć, że wyznaczane przez różnych autorów regiony nie mają charakteru kompleksowego. Niektórzy delimitują zasięgi dużych miast (por. Smętkowski et al. 2009; Pielesiak, 2012; Śleszyński, 2013), inni ograniczają się tylko do miast średnich lub małych. Brakuje w Polsce ujęcia całościowego i kompleksowego, czyli takiego, gdzie w procesie delimitacji uwzględniono by wyjściowo cały obszar Polski, na równi miasta duże, średnie, jak i gminy wiejskie. To podejście, choć w innym ujęciu, ale z mało przejrzystym efektem (co niestety utrudnia jego zastosowanie), przedstawia w swojej procedurze Gruchociak (2012).

Z powyższych powodów, przede wszystkich stosowanego podejścia hierarchicznego, często spotykanego w opisanych procedurach delimitacyjnych, autorzy wykorzystali delimitację zaproponowaną przez Marcińczaka i Bartosiewicza (2018) i wyznaczyli regiony miejskie z zastosowaniem podejścia strukturalnego - algorytmu działającego na podstawie analizy sieci, wykorzystując w tym celu narzędzie COMBO (Sobolewsky et al., 2014) oraz analizy siły powiązań (Hincks, 2012).

COMBO jest algorytmem aprzestrzennym, czyli nie bierze pod uwagę wielkości miast czy ich geograficznego położenia. To jest jego duża zaleta na tle innych delimitacji. Bada wszystkie relacje - wielkość rynku pracy czy liczba mieszkańców miasta nie jest brana pod uwagę. Jest to algorytm charakteryzujący się najwyższą modularnością wyników pośród najbardziej popularnych algorytmów wykorzystywanych w badaniach sieci, jak np. TTWA w Wielkiej Brytanii (travel to work areas) czy algorytm europejski w Danii (Gruchociak, 2012). W toku procedury delimitacyjnej COMBO uwzględnia jedynie kierunek i wielkość relacji w sieci. Dodatkowo COMBO to narzędzie, które nawet w przypadku bardzo dużego zbioru danych - węzłów (jednostek, pomiędzy którymi badane są powiązania) i relacji, cechuje się krótkim czasem wykonywania analizy oraz niedużymi wymaganiami sprzętowymi.

Tak jak ma to miejsce w przypadku wielu delimitacji regionów miejskich, rozumianych jako dziennych systemów miejskich, podstawą badania są informacje na temat powiązań funkcjonalnych. Najczęściej, ze względu na dostęp do najbardziej kompleksowych i porównywalnych danych, korzysta się z informacji o dojazdach do pracy. Dojazdy do pracy to nie tylko najtrwalsze z powiązań przestrzennych, ale są one także swoistym barome- 
trem szeregu innych powiązań: transportowych, dojazdów do placówek handlowych czy dojazdów do placówek oświatowych.

W odróżnieniu od Marcińczaka i Bartosiewicza (2018), którzy delimitują regiony dla roku 2011, proponowana w tej pracy delimitacja wykorzystuje dane dla dwóch lat: 1983 i 2011. Dla obu lat wyznaczamy regiony z zastosowaniem algorytmu COMBO. Wykorzystano w tym celu dane na temat dojazdów do pracy z 1983 r. ${ }^{3}$ i dla roku 2011. Zdecydowano się wykorzystać jedynie dane o dojazdach do pracy, które odbywają się na odległość (pomiędzy centroidami gmin) nie większą niż $30 \mathrm{~km}$, czyli ok. $40 \mathrm{~km}$ po drogach ${ }^{4}$ (dystans ten jest liczony w linii prostej) $)^{5}$. Otrzymane odrębnie dla obu badanych lat wyniki zostały tak uporządkowane, aby w myśl zasady regionalizacji, powstały spójne i ciągłe przestrzennie regiony miejskie. Ze względu na fakt, że działanie algorytmu polega na łączeniu ze sobą podgrafów w większe grafy, nawet jeżeli połączenia pomiędzy tymi grafami opierają się na pojedynczej krawędzi, łączącej najczęściej wierzchołki odpowiadające głównym ośrodkom miejskim, zmodyfikowano otrzymane wyniki wykorzystując w tym celu klasyfikację Hincksa (2012). Polega ona na wyznaczeniu trzech klas dojazdów do pracy dla każdego regionu miejskiego według wielkości obserwowanych przepływów (gdzie pierwsza klasa obejmuje największe przepływy). Metoda ta opiera się na standaryzacji danych z wykorzystaniem wartości średniej i odchylenia standardowego. Wyznaczenie trzech klas jest relatywne i wykonywanie niezależnie dla każdego regionu miejskiego. Modyfikacja wyników delimitacji otrzymanych z zastosowaniem algorytmu COMBO polegała na rozdzieleniu regionów, które charakteryzowały się pojedynczym powiązaniem (niezależnie od jego rodzaju). Miało to miejsce często pomiędzy większymi miastami (np. Słupsk-Koszalin czy Bydgoszcz-Toruń). W przypadku kiedy regiony składały się z dwóch czytelnych podregionów, w ramach których koncentrowały się wszystkie dojazdy I rzędu i II rzędu według Hinkcsa, a pomiędzy nimi obserwowano jedynie nieliczne powiązania III rzędowe, również dokonywano rozdzielenia regionów. Finalnie otrzymano dwie delimitacje: dla 1983 i 2011 r. Następnie te wyniki nałożono na siebie.

W wyniku nałożenia na siebie wyników delimitacji dla obu badanych lat otrzymano 56 regionów miejskich. Dany region miejski składa się z gmin, które przynależały do niego w obu badanych okresach. Rozmieszczenie tych regionów prezentuje ryc. 3, a krótki opis statystyczny - tab. 1 .

Takie podejście do delimitacji regionów miejskich spowodowane jest dwoma podstawowymi przyczynami. Po pierwsze chcieliśmy otrzymać takie wyniki delimitacji, które posłużą nam również do badania zmian poziomu policentryczności w przyszłości, a w takim przypadku zawsze pojawia się problem, jakie regiony powinny takiej analizie podlegać. Czy mamy zmiany policentryczności mierzyć dla regionów współczesnych czy historycznych? Autorzy analizujący zmiany policentryczności dla Niemiec (Schmitt et al., 2015) oraz Anglii i Walii (Burger et al., 2011) posłużyli się w tym celu regionami wyznaczonymi

\footnotetext{
3 Jest to macierz danych zawierająca informacje na temat międzygminnych dojazdów do pracy w 1983 r. pochodzących z przeprowadzonego wówczas Spisu Kadrowego. Dane obejmują jedynie pracę najemną i są ostatnimi badaniami zawierającymi kompleksowe informacje o dojazdach w Polsce przed 1989 r. Dane te są dostępne jedynie w wersji papierowej, co wiązało się z potrzebą ich digitalizacji.

${ }^{4}$ Przyjmując wskaźnik rozwinięcia (tzw. prostolinijności) sieci drogowej na poziomie 1,2-1,3.

${ }^{5}$ We wspomnianym badaniu z 2018 r. (Marcińczak i Bartosiewicz, 2018) posłużono się w tym celu bardziej dokładnymi danymi na temat czasu przejazdu samochodem po drogach. Taka analiza nie jest możliwa dla roku 1983 ze względu na brak odpowiednich danych oraz niepoprawność zastosowania takiego rozwiązania, kiedy przemieszczanie się samochodem nie było tak powszechne jak dzisiaj.
} 


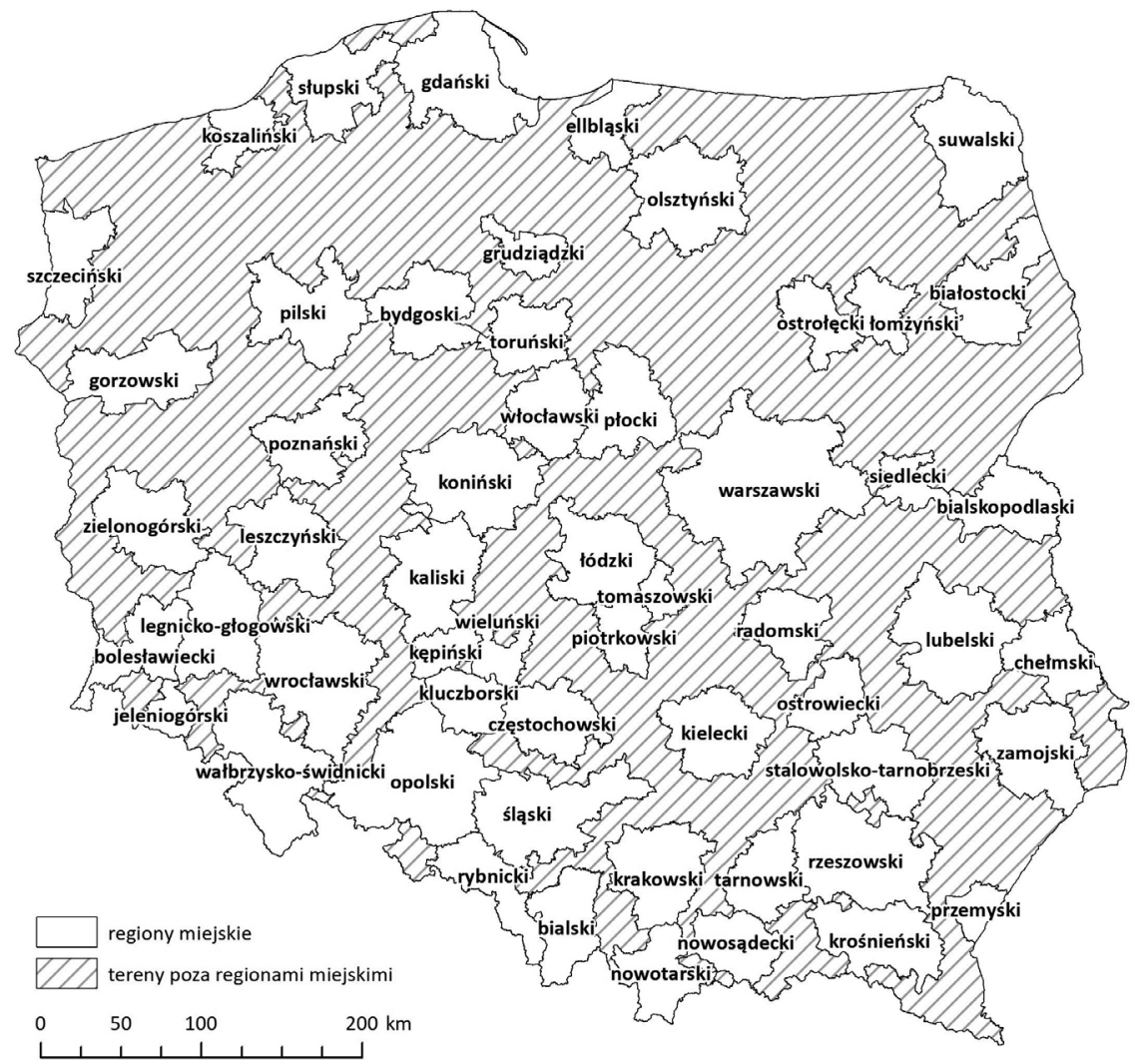

Ryc. 3. Regiony miejskie w Polsce na podstawie autorskiej delimitacji Urban regions in Poland based on authors' delimitation

Tabela 1. Opis statystyczny regionów miejskich w Polsce (według stanu na koniec 2011 r.) Statistical description of urban regions in Poland (2011)

\begin{tabular}{|l|c|c|c|c|}
\hline \multicolumn{1}{|c|}{ Cecha } & Maks. & Min. & Średnia & Odchylenie stand. \\
\hline Liczba gmin & 117 & 7 & 28 & 19 \\
Ludność (tys.) & 3173 & 78,2 & 492,3 & 6552,4 \\
Powierzchnia (tys. km²) & 8,6 & 0,6 & 2,6 & 1,4 \\
Pracujący (tys.) & 2078 & 26,7 & 224,2 & 326 \\
\hline
\end{tabular}

współcześnie. Takie podejście wydaje się autorom nie do końca poprawne, w szczególności w przypadku Polski. Zmiany struktury przestrzennej i dynamika procesów społeczno-gospodarczych w Polsce, która miała miejsce w przeciągu ostatnich kilkudziesięciu lat, były na tyle duże, że porównywanie ze sobą sytuacji sprzed okresu transformacji z sytuacją współczesną wydaje się być błędne. Z tych samych powodów wadliwe wydaje się zbadanie policentryczności w 1983 r. dla regionów wyznaczonych historycznie i w 2011 r. dla regionów wyznaczonych współcześnie. W tym przypadku narażamy się na odmienną wielkość regionów, a nawet inną ich liczbę. 
Z tego względu autorzy proponuje inne podejście, u którego podstaw stoi opisane powyżej wykorzystanie algorytmu COMBO. Jest to metoda, która ogranicza do jednej decyzje subiektywne podejmowane w procesie delimitacji. Jednocześnie autorzy mają świadomość, że tak wyznaczone regiony są najczęściej (choć nie zawsze) mniejsze niż delimitowane współcześnie.

Największym pod względem wszystkich analizowanych cech jest region warszawski. Najmniejszym pod względem powierzchni i liczby gmin jest region tomaszowski, a pod względem liczby mieszkańców oraz pracujących - region wieluński. Rozmieszczenie regionów miejskich pokrywa się z gęstością sieci osadniczej i największą ich koncentrację obserwujemy w Polsce południowo-zachodniej.

\section{Dane}

W celu pomiaru policentryczności regionów miejskich w Polsce wykorzystano dwa rodzaje danych. Pierwsze to macierz międzygminnych przepływów pracowniczych z 1983 r. (Spis Kadrowy, 1983) oraz 2011 r. (GUS). Drugim źródeł informacji jest liczba pracujących w gminach. Dla 1983 r. skorzystaliśmy z danych z roczników statystycznych województw. Dla 2011 r. liczba ta została oszacowana jako suma liczby pracujących według GUS (obejmuje tych pracujących w podmiotach zatrudniających powyżej 9 osób) oraz iloczyn podmiotów gospodarczych zatrudniających do 9 osób oraz przeciętnego zatrudnienia w tej grupie wielkościowej firm (dla 2011 r. według GUS wartość ta wyniosła 1,98). Pozostałe dane wykorzystane w trakcie analiz pochodzą z: Banku Danych Lokalnych GUS, CUGIK oraz OSM (Open_Street_Maps).

\section{Wyniki}

Regiony miejskie w Polsce cechują się zróżnicowaną strukturą przestrzenną (tab. 2). Przeciętnie są one bardziej policentryczne funkcjonalnie niż morfologicznie - charakteryzuje je większa różnorodność rozkładu dojazdów do pracy niż miejsc pracy. Gęstość sieci (ND) - odsetek dojeżdżających do pracy w ogóle pracujących w regionie oscyluje wokół $12 \%$, a ich otwartość nie przekracza 13\%. W wymiarze morfologicznym najbardziej policentryczny jest region śląski - uznawany za wzorcowy region policentryczny w Polsce. Wartym odnotowania jest fakt, że funkcjonalnie region ten jest mniej policentryczny niż

Tabela 2. Statystyki opisowe dla wskaźników policentryczności funkcjonalnej (FP), morfologicznej (MP), gęstości sieci (ND) oraz otwartości (OO) dla regionów w Polsce

Descriptive statistics for indices of functional polycentricity (FP), morphological polycentricity (MP), network density (ND) and openness (OO) in the case of urban regions in Poland

\begin{tabular}{|l|c|c|c|c|}
\hline \multicolumn{1}{|c|}{ Wskaźnik } & $\overline{1}$ & $\alpha$ & Maks. & Min. \\
\hline PF & 0,53 & 0,15 & 0,89 & 0,23 \\
PM & 0,47 & 0,18 & 0,80 & 0,22 \\
FP-MP & 0,06 & 0,10 & 0,33 & $-0,17$ \\
ND & 0,12 & 0,05 & 0,26 & 0,05 \\
OO & 0,05 & 0,02 & 0,13 & 0,01 \\
\hline
\end{tabular}


za niego uchodzi. Jest nie tylko mniej policentryczny od małych regionów górniczych: rybnickiego, legnicko-głogowskiego czy obecnie już pogórniczego wałbrzysko-świdnickiego, ale także od regionu gdańskiego, opolskiego czy bialskiego (ryc. 4A).

Najbardziej monocentryczne - w wymiarze morfologicznym - są regiony miejskie większych miast: Szczecina, Białegostoku, Bydgoszczy i Krakowa, w dalszej kolejności także miast średnich: Grudziądza, Siedlec oraz Radomia. Generalnie większość polskich aglomeracji jest bardziej monocentryczna morfologicznie, niż funkcjonalnie, co można tłumaczyć procesem suburbanizacji. Ludność odpływa z miast do gmin sąsiednich, a miejsca pracy pozostają w miastach. Do najbardziej monocentrycznych funkcjonalnie należą regiony małe, obejmujące jeden, ewentualnie dwa ośrodki miejskie: przemyski, wieluński czy ostrołęcki. Generalnie brak jest związku pomiędzy wielkością regionu miejskiego czy miasta centralnego (wyrażonych liczbą mieszkańców) a poziomem policentryczności morfologicznej czy funkcjonalnej. Kluczową cechą regionów miejskich jest za to silna zależność pomiędzy poziomem policentryczności morfologicznej i funkcjonalnej (tab. 3). Im mniejszy udział pracujących w głównym mieście (regionu), tym bardziej zróżnicowany jest rozkład dojazdów do pracy w regionie miejskim.

Niewielki jest za to udział regionów, które (według progu ustalonego na poziomie 0,5$)$ są monocentryczne funkcjonalnie i policentryczne morfologicznie (ten przypadek i to na granicy przedziału reprezentowany jest tylko przez region zamojski), jak i tych monocentrycznych morfologicznie i policentrycznych funkcjonalnie - taka sytuacja występuje w 11 regionach. Są to zarówno regiony większych ośrodków miejskich - Wrocławia, Poznania czy Szczecina, jak i tych małych np. bolesławiecki, łomżyński czy elbląski. W ich przypadku przyczyn tego zjawiska można upatrywać w silnych procesach suburbanizacyjnych, czego Poznań jest najlepszym przykładem. Równomiernie rozkłada się liczba regionów miejskich w pozostałych dwóch grupach. O jeden więcej jest regionów monocentrycznych funkcjonalnie i morfologicznie. Do tego podziału ściśle nawiązują typy policentryczności.

Policentryczność morfologiczna regionu jest również silnie zależna od gęstości sieci (ND) (por. ryc. 4B). Im region miejski cechuje się mniejszą koncentracją miejsc pracy w głównym ośrodku miejskim, tym wśród pracujących wzrasta odsetek tych dojeżdżających do pracy. To znajduje swoje potwierdzenie w innej obserwacji - zależności pomiędzy ND (gęstością sieci) oraz różnicą wartości policentryczności funkcjonalnej oraz morfologicznej. Im regiony bardziej policentryczne funkcjonalnie niż morfologicznie, tym udział dojazdów do pracy w ogóle pracujących w regionie miejskim jest mniejszy.

Tabela 3. Zależność pomiędzy policentrycznością funkcjonalną (PF), morfologiczną (MP), gęstością sieci (ND) oraz otwartością (OO) dla regionów miejskich w Polsce

Correlations between functional polycentricity (FP), morphological polycentricity (MP), network density (ND) and openness $(\mathrm{OO})$ in the case of urban regions in Poland

\begin{tabular}{|l|c|c|c|c|c|}
\hline \multicolumn{1}{|c|}{ Wskaźnik } & FP & MP & FP-MP & ND & OO \\
\hline FP & 1,00 & & & & \\
MP & $\mathbf{0 , 8 2}$ & 1,00 & & & \\
FP-MP & $-0,01$ & $-0,58$ & 1,00 & & \\
ND & 0,51 & $\mathbf{0 , 7 6}$ & $\mathbf{- 0 , 6 1}$ & 1,00 & \\
OO & $-0,01$ & 0,17 & $-0,32$ & 0,25 & 1,00 \\
\hline
\end{tabular}


A

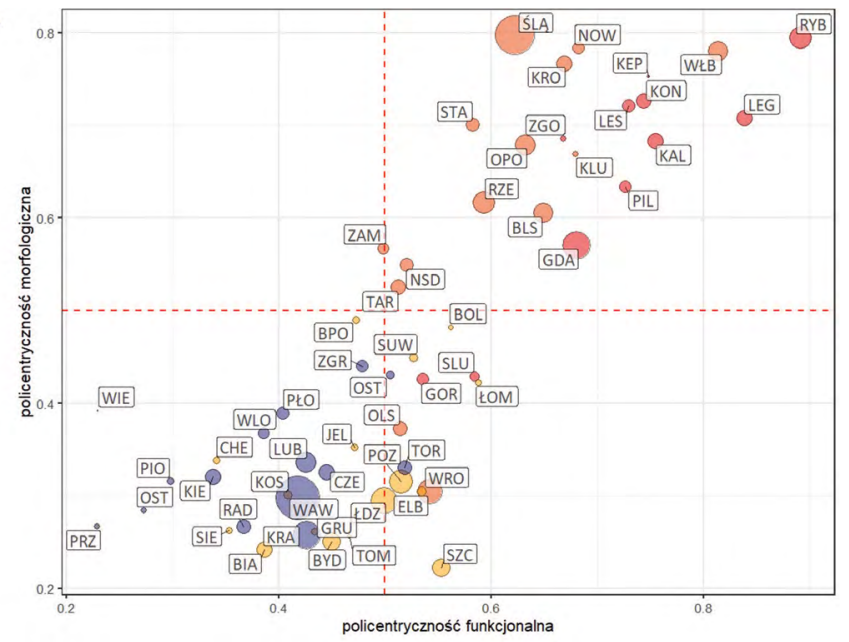

B

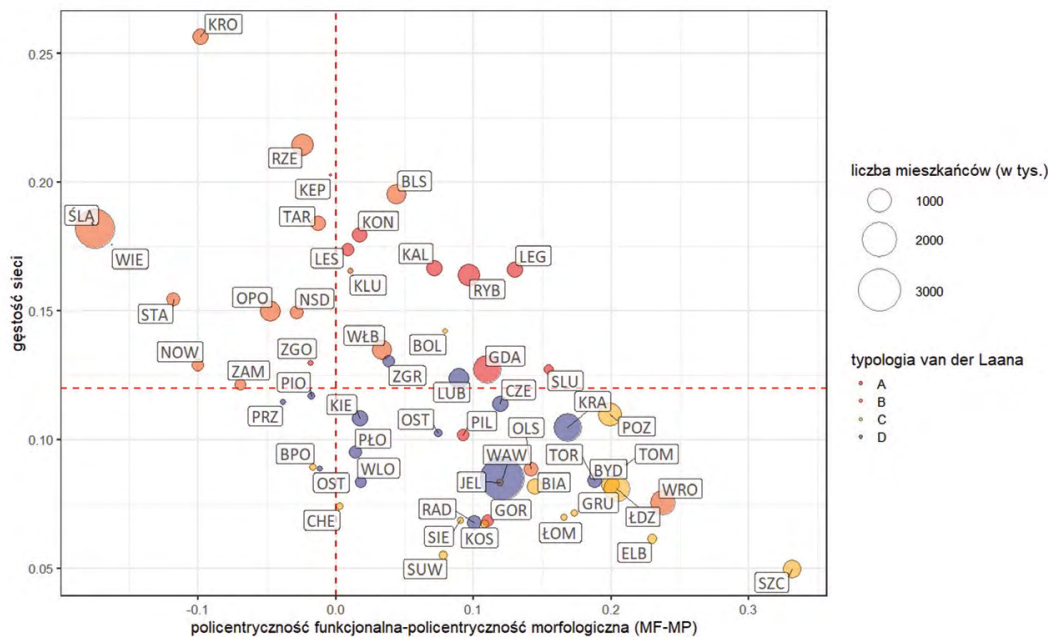

Ryc. 4. Zależność pomiędzy policentrycznością funkcjonalną i morfologiczną (A) oraz gęstością sieci i różnicą policentryczności funkcjonalnej oraz morfologicznej w regionach miejskich w Polsce według liczby mieszkańców i typów policentryczności van der Laana

BIA - białostocki, BLS - bialski, BOL - bolesławiecki, BPO - bialskopodlaski, BYD - bydgoski, CHE - chełmski, CZE - częstochowski, ELB - elbląski, GDA - gdański, GOR - gorzowski, GRU - grudziądzki, JEL - jeleniogórski, KAL - kaliski, KEP - kępiński, KIE - kielecki, KLU - kluczborski, KON - koniński, KOS - koszaliński, KRA - krakowski, KRO - krośnieński, ŁDZ - łódzki, LEG - legnicko-głogowski, LES - leszczyński, ŁOM - łomżyński, LUB - lubelski, NOW - nowotarski, NSD - nowosądecki, OLS - olsztyński, OPO - opolski, OST - ostrowiecki, OSR - ostrołęcki, PIL - pilski, PIO - piotrkowski, PŁO - płocki, POZ - poznański, PRZ - przemyski, RAD - radomski, RYB - rybnicki, RZE - rzeszowski, SIE - siedlecki, ŚLA - śląski, SLU - słupski, STA - stalowolsko-tarnobrzeski, SUW - suwalski, SZC - szczeciński, TAR - tarnowski, TOM - tomaszowski, TOR - toruński, WAW - warszawski, WŁB - wałbrzysko-świdnicki, WIE - wieluński, WŁO - włocławski, WRO - wrocławski, ZAM - zamojski, ZGO - zgorzelecko-lubański, ZGR - zielonogórski.

Typy van der Laana: A - policentryczny z dużym udziałem zwrotnych relacji z pominięciem miasta centralnego (criss-cross), B - policentryczny zdecentralizowany (decentralized), C - policentryczny z przewagą relacji zwrotnych (exchange), D - monocentryczny (moncetric) Correlation between functional and morphological polycentricity $(A)$ and network density; and difference between the morphological and functional polycentricity of urban regions in Poland (by number of inhabitants and types of polycentricity after van der Laan's polycentricity typology) 
Silne zależności obserwuje się również pomiędzy policentrycznością regionów a ich położeniem (ryc. 5). Te nawiązują jeszcze do podziałów zaborowych, czego konsekwencją jest silnie zróżnicowana sieć osadnictwa miejskiego. Monocentryczne są prawie w całości regiony Mazowsza, ziemi łódzkiej, Kielecczyzny, Podlasia i Lubelszczyzny. Nieliczne są przykłady regionów monocentrycznych z innych części kraju. Warto również zwrócić uwagę na rozmieszczenie poszczególnych typów policentryczności. Szczególną uwagę przykuwają regiony zdecentralizowane (decentralized). Dominują one na południu Polski i ich rozmieszczenie należy tłumaczyć dwoma czynnikami. Pierwszy z nich to obecne lub pierwotne znaczenie działalności górniczej oraz przemysłowej w tych regionach. Drugim czynnikiem może być ich położenie związane z ukształtowaniem terenu.

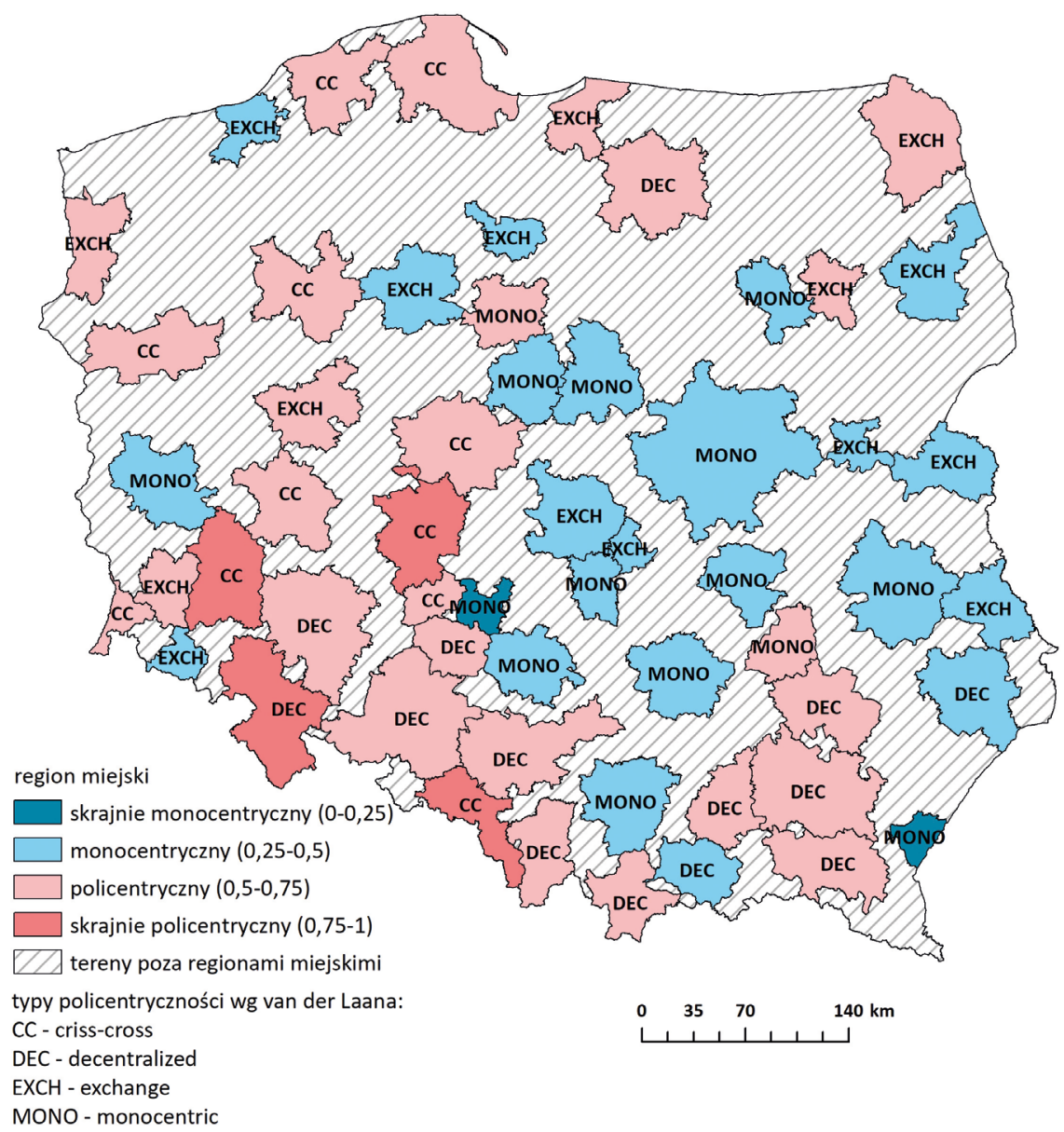

Ryc. 5. Zróżnicowanie policentryczności funkcjonalnej regionów miejskich w Polsce Differentiation to the functional polycentricity noted for urban regions in Poland 


\section{Wnioski i dyskusja}

Przedstawiony pomiar struktury przestrzennej regionów miejskich to nowe podejście dotychczas niespotykane w literaturze polskiej. Wykracza ono poza tradycyjne, ugruntowane w Polsce od lat 70. czy 80. XX w. rozumienie policentryczności regionu miejskiego. Wielką zaletą tego podejścia jest spojrzenie na regiony miejskie i ich strukturę przestrzenną z punktu widzenia zarówno morfologicznego, jak i funkcjonalnego. A otrzymane wyniki wskazują na interesujące zależności występujące w tych dwóch ujęciach. Poziom policentryczności w regionach miejskich jest zróżnicowany i nie zawsze najwyższy w tych, które tradycyjne za takie uchodzą. Obok regionów typowo policentrycznych liczna grupę stanowią układy monocentryczne, i to zarówno funkcjonalnie, jak i morfologicznie. Jednocześnie obserwujemy podobne zależności strukturze regionów miejskich w Polsce stosunku do badań zagranicznych (Burger i Meijers, 2012). Wraz ze wzrostem miejsc pracy poza miastem głównym rośnie ilość dojazdów do pracy z gminy zamieszkania. Nie zaskakuje związek pomiędzy strukturą przestrzenną regionu a jej położeniem historycznym (granice zaborów), zaskakuje za to wyrazistość tych podziałów, którą utrzymują się do dzisiaj.

Poczynione obserwacje skłaniają do dalszych studiów nad policentrycznością regionów miejskich, wśród których powinna się znaleźć próba wyjaśnienia tych zjawisk oraz uchwycenie zmian tego zjawiska w czasie, jak również pomiar policentryczności w skali ponadregionalnej.

Oryginalnym efektem badania jest również zaprezentowana delimitacja regionów miejskich. Jest to jedna z nielicznych całościowych współcześnie propozycji delimitacji, która bazuje na związkach funkcjonalnych (w tym przypadku dojazdach do pracy) i wyznacza - kierując się tymi samymi kryteriami - regiony miejskie bez dodatkowych założeń (np. wielkości głównego miasta, zasięgu, funkcji administracyjnej itp.). Algorytm COMBO jest bardzo ciekawym narzędziem, ale niepozbawionym wad. Autorzy zdając sobie z tego sprawę weryfikują dodatkowo otrzymane wyniki. Można się spierać o szczegóły granic poszczególnych regionów (czy zasięg regionów jest za duży albo za mały), ale należy stwierdzić, że otrzymane wyniki są więcej niż zadawalające. Pokrywają się z licznymi przykładami delimitacji pojedynczych regionów wykonywanych np. na potrzeby prac planistycznych.

Ryciny i tabele, pod którymi nie zamieszczono źródła, są opracowaniami własnymi autorów artykułu.

Badania, których wyniki opublikowano w artykule, finansowane są ze środków Narodowego Centrum Nauki (numer grantu: DEC-2015/19/HS4/01289).

\section{Piśmiennictwo}

Alonso, W. (1964). Location and Land Use: Towards a general history of land rent. Cambridge, Mass.: Harvard University Press. https://doi.org/10.2307/142015

Bański, J., Czapiewski, K., \& Mazur, M. (2012). Policentryczność rozwoju Mazowsza. Mazowsze. Studia Regionalne, 10, 71-88. 
Bartosiewicz, B. (2016). Wyznaczanie miejskich obszarów funkcjonalnych o znaczeniu ponadlokalnym na potrzeby planistyczne - przykład województwa łódzkiego. Zarzqdzanie Publiczne, 37, 38-51, http://doi.org/10.15678/ZP.2016.37.3.03

Blazy, R. (2008). Aglomeracja policentryczna jako organizm „bez serca” - na przykładzie górnośląskiego obszaru metropolitalnego. Czasopismo Techniczne, 105(2), 55-61.

Boussauw, K., Derudder, B., \& Witlox, F. (2011). Measuring spatial separation processes through the minimum commute: the case of Flanders. European Journal of Transport and Infrastructure Research, 11(1), 42-60. https://doi.org/10.18757/ejtir.2011.11.1.2911

Burgalassi, D. (2010). Defining and measuring polycentric regions: the case of Tuscany. Pobrane z: https://scholar.google.pl/scholar? cluster=6983367515697200651\&hl=pl\&as_sdt=0,5 (03.01.2018).

Burger, M.J., Goei, B., van der Laan, L., \& Huisman, F.J.M. (2011). Heterogeneous development of metropolitan spatial structure: Evidence from commuting patterns in English and Welsh city-regions, 1981-2001. Cities, 28(2), 160-170. https://doi.org/10.1016/j.cities.2010.11.006

Burger, M., \& Meijers, E. (2012) Form follows function? Linking morphological and functional polycentricity. Urban Studies, 49(5), 1127-1149. https://doi.org/10.1177/0042098011407095

Camagni, R., Gibelli, M.C., Rigamonti, P. (2002). Urban mobility and urban form: the social and environmental costs of different patterns of urban expansion. Ecological Economics, 40(2), 199-216. https://doi.org/10.1016/s0921-8009 (01)00254-3

CEC. (1999). European spatial development perspective: Towards balanced and sustainable development of the territory of the EU. Luxembourg: Office for Official Publications of the European Communities.

Cirilli, A., \& Veneri, P. (2014). Spatial structure and carbon dioxide $\left(\mathrm{CO}_{2}\right)$ emissions due to commuting: An analysis of Italian urban areas. Regional Studies, 48(12), 1993-2005. https://doi.org/10.1080/00343404.2013.827333

Clark, W.A.V., Huang, Y., \& Withers, S. (2003). Does commuting distance matter? Commuting tolerance and residential change. Regional Science and Urban Economics, 33(2), 199-221. https://doi.org/10.1016/S0166-0462 (02)00012-1

Davoudi, S. (2003). European Briefing: Polycentricity in European spatial planning: from an analytical tool to a normative agenda. European Planning Studies, 11(8), 979-999. https://doi.org/10.1080/0965431032000146169

De Goei, B., Burger, M.J., Oort, F.G., \& Kitson, M. (2010). Functional Polycentrism and Urban Network Development in the Greater South East, United Kingdom: Evidence from commuting patterns, 1981-2001. Regional Studies, 44(9), 1149-1170. https://doi.org/10.1080/00343400903365102

Deng, Y., Liu, J., Liu, Y., \& Luo, A. (2019). Detecting Urban Polycentric Structure from POI Data. ISPRS International Journal of Geo-Information, 8(6), 283. https://doi.org/10.3390/ijgi8060283

ESPON 1.1 .1 (2004). Potentials for polycentric development in Europe. Project Report. Stockholm/ Luxembourg: Nordregio/ESPON Monitoring Committee. Pobrane z: espon.eu

ESPON 1.4.3. (2007). Study on Urban Functions, Final report, Brussels/Luxembourg: ULB/ESPON Monitoring Committee. Pobrane z: espon.eu (03.01.2018).

Faludi, A. (2006). From European spatial development to territorial cohesion policy. Regional Studies, 40(6), 667-678. https://doi.org/10.1080/00343400600868937

Fawcett, C.B. (1932). Distribution of the urban population in Great Britain, 1931. The Geographical Journal, 79(2), 100-113. https://doi.org/10.2307/1785089

Geddes, P. (1915). City in evolution. London: Williams and Norgate Ltd.

Gorzelak, G., \& Smętkowski, M. (2005). Metropolia i jej region w gospodarce informacyjnej. Scholar Books. 
Green, N. (2007). Functional polycentricity: A formal definition in terms of social network analysis. Urban Studies, 44(11), 2077-2103. https://doi.org/10.1080/00420980701518941

Green, N. (2008). City-states and the spatial in-between. Town and Country Planning, 77(5).

Growe, A. (2012). Emerging polycentric city-regions in Germany. Regionalisation of economic activities in metropolitan regions. Erdkunde, 66(4), 295-331. https://doi.org/10.3112/erdkunde.2012.04.02

Gruchociak, H. (2012). Delimitacja lokalnych rynków pracy w Polsce. Przeglqad Statystyczny, 59(2), 277-297.

Hall, P.G., \& Pain, K. (red.). (2006). The polycentric metropolis: learning from mega-city regions in Europe. Routledge.

Harris, C.D., Ullman, E.L. (1945). The nature of cities. The Annals of the American Academy of Political and Social Science, 242(1), 7-17. https://doi.org/10.4324/9780203543047-7

Heffner, K., \& Gibas, P. (2015). Obszary funkcjonalne i ich związki z zasięgiem oddziaływania ośrodków subregionalnych (na przykładzie województwa opolskiego). Studia Miejskie, 18, 10-23.

Heffner, K., \& Gibas, P. (2017). Centra regionów a spójność regionalna w Polsce. Prace Naukowe Uniwersytetu Ekonomicznego we Wroclawiu, 466. https://doi.org/10.15611/pn.2017.466.10

Hincks, S. (2012). Daily Interaction of Housing and Labour Markets in North West England. Regional Studies, 46(1), 83-104. https://doi.org/10.1080/00343404.2010.486782

Kloosterman, R.C., \& Lambregts, B. (2001). Clustering ofeconomic activities in polycentricurban regions:the case of the Randstad. Urban Studies, 38(4), 717-732. https://doi.org/10.1080/00420980120035303

Kloosterman, R.C., \& Musterd, S. (2001). The polycentric urban region: towards a research agenda. Urban Studies, 38(3), 623-633. https://doi.org/10.1080/00420980120035259

Komornicki, T., Czapiewski, K., \& Solon, B. (2012). Zagospodarowanie infrastrukturalne i kapitał fizyczny oraz policentryczność rozwoju Mazowsza. Trendy Rozwojowe Mazowsza, 4. Warszawa: Mazowieckie Biuro Planowania Regionalnego.

Komornicki, T., Korcelli, P., Siłka, P., Śleszyński, P., \& Świątek, D. (2013). Powiq̨zania funkcjonalne pomiędzy polskimi metropoliami. Warszawa: Wydawnictwo Akademickie SEDNO.

Korcelli, P. (2004). Koncepcja policentryczności systemów miejskich w ujęciu Europejskiej Perspektywy Rozwoju Przestrzennego. Europa XXI, 11, 37-43. https://doi.org/10.7163/Eu21.2004.11

Korcelli, P. (2005a). Pojęcie policentryczności a współczesne przemiany systemów miast. Biuletyn Komitetu Przestrzennego Zagospodarowania Kraju PAN, 219. Warszawa: Komitet Przestrzennego Zagospodarowania Kraju PAN.

Korcelli, P. (2005b). The urban system of Poland. Built Environment, 31(2), 133-142. https://doi.org/10.2148/benv.31.2.133.66251

Korcelli, P., \& Śleszyński, P. (2008). Delimitacja Funkcjonalnych Obszarów Miejskich 2006 (Mapa $\mathrm{nr}$ 7), W: P. Korcelli (red.) Ekspercki projekt koncepcji przestrzennego zagospodarowania kraju do roku 2033, (s. 23).

Korcelli-Olejniczak, E. (2004). Funkcje metropolitalne Berlina i Warszawy w latach 1990-2002: współzależność pozycji w systemie miast Europy Środkowej. Prace Geograficzne, 198. Warszawa: IGiPZ PAN.

Krugman, P.R. (1993). Geography and Trade. MIT Press.

Krzysztofik, R., Tkocz, M., Spórna, T., \& Kantor-Pietraga, I. (2016). Some dilemmas of post-industrialism in a region of traditional industry: The case of the Katowice conurbation, Poland. Moravian Geographical Reports, 24(1), 42-54.

Kurek, S., Wójtowicz, M., \& Gałka, J. (2020). Population Growth in Functional Urban Areas in Poland. W: S. Kurek, M. Wójtowicz, \& J. Gałka (red.), Functional Urban Areas in Poland (s. 33-50). Cham: Springer. 
Leszczycki, S., Eberhardt, P., \& Herman, S. (1971). Aglomeracja miejsko-przemysłowe w Polsce 1966-2000. Warszawa: PWN.

Limtanakool, N., Dijst, M., \& Schwanen, T. (2007). A theoretical framework and methodology for characterising national urban systems on the basis of flows of people: empirical evidence for France and Germany. Urban Studies, 44(11), 2123-2145.

https://doi.org/10.1080/00420980701518990

Limtanakool, N., Schwanen, T., \& Dijst, M. (2009). Developments in the Dutch urban system on the basis of flows. Regional Studies, 43(2), 179-196. https://doi.org/10.1080/00343400701808832

Lin, D., Allan, A., \& Cui, J. (2015). The impact of polycentric urban development on commuting behaviour in urban China: evidence from four sub-centres of Beijing. Habitat International, 50, 195-205. https://doi.org/10.1016/j.habitatint.2015.08.018

Liu, X., \& Wang, M. (2016). How polycentric is urban China and why? A case study of 318 cities. Landscape and Urban Planning, 151, 10-20. https://doi.org/10.1016/j.landurbplan.2016.03.007

Liu, X., Derudder, B., \& Wu, K. (2016). Measuring polycentric urban development in China: An intercity transportation network perspective. Regional Studies, 50(8), 1302-1315. https://doi.org/10.1080/00343404.2015.1004535

Malý, J. (2016). Impact of polycentric urban systems on intra-regional disparities: A micro-regional approach. European Planning Studies, 24(1), 116-138. https://doi.org/10.1080/09654313.2015.1054792

Marcińczak, S., \& Bartosiewicz, B. (2018). Commuting patterns and urban form: Evidence from Poland. Journal of Transport Geography, 70. https://doi.org/10.1016/j.jtrangeo.2018.05.019

Markowski, T., \& Marszał, T. (red.) (2002), Polycentric metropolitan regions - new concepts and experiences. Studia Regionalia KPZK PAN, 11. Warszawa: Komitet Przestrzennego Zagospodarowania Kraju PAN.

Markowski, T., \& Marszał, T. (2005). Funkcje i zarządzanie obszarami metropolitalnymi. Samorząd Terytorialny, 7-8, 7-16.

Marszał, T. (2017). Łódź Metropolitan Area: Delimitation, planning and development. Geographia Polonica, 90(3), 281-300. https://doi.org/10.7163/gpol.0096

Meijers, E. (2008a). Measuring polycentricity and its promises. European Planning Studies, 16(9), 1313-1323. https://doi.org/10.1080/09654310802401805

Meijers, E. (2008b). Summing small cities does not make a large city: polycentric urban regions and the provision of cultural, leisure and sports amenities. Urban Studies, 45(11), 2323-2342. https://doi.org/10.1177/0042098008095870

Meijers, E., Hoogerbrugge, M., \& Cardoso, R. (2017). Beyond Polycentricity: Does Stronger Integration Between Cities in Polycentric Urban Regions Improve Performance?. Tijdschrift voor Economische en Sociale Geografie, 109(1), 1-21. https://doi.org/10.1111/tesg.12292

Melo, P.C., Graham, D.J., \& Noland, R.B. (2012). The effect of labour market spatial structure on commuting in England and Wales. Journal of Economic Geography, 12(3), 717-737. https://doi.org/10.1093/jeg/lbr011

Mikuła, Ł., \& Kaczmarek, T. (2017). Metropolitan integration in Poland: the case of Poznań Metropolis. International Planning Studies, 22(1), 30-43. https://doi.org/10.1080/13563475.2016.1256191

Pielesiak, I. (2012). Delimitacja i instytucjonalizacja Łódzkiego Obszaru Metropolitalnego, W: B Bartosiewicz, I. Pielesiak, \& T. Marszał (red.). Spójność terytorialna Łódzkiego Obszaru Metropolitalnego, Studia KPZK PAN, 147 (s. 139-154). Warszawa: Komitet Przestrzennego Zagospodarowania Kraju PAN. 
Porter, M.E. (1990). The competitive advantage of nations. Competitive Intelligence Review, 1(1). https://doi.org/10.1002/cir.3880010112

Potrykowska, A. (1989). Funkcjonalne regiony miejskie w krajowym systemie osadniczym. W: P. Korcelli, \& A. Gawryszewski (red.), Wspótczesne przemiany regionalnych systemów osadniczych w Polsce. Prace Geograficzne, 152 (s. 55-75). Warszawa: Instytut Geografii i Przestrzennego Zagospodarowania PAN.

Rauhut, D. (2017). Polycentricity - one concept or many? European Planning Studies, 25(2), 332-348. https://doi.org/10.1080/09654313.2016.1276157

Rosik, P., Stępniak, M., \& Wiśniewski, R. (2010). Dojazdy do pracy do Warszawy i Białegostoku- alternatywne podejścia metodologiczne. Studia Regionalne i Lokalne, 40(2), 77-98.

Schmitt, P., Volgmann, K., Münter, A., \& Reardon, M. (2015). Unpacking polycentricity at the city-regional scale: Insights from Dusseldorf and Stockholm. European Journal of Spatial Development, $59,1-26$.

Scott, A.J. (1988). Metropolis: From the division of labor to urban form. University of California Press.

Shu, X., Han, H., Huang, C., \& Li, L. (2020). Defining functional polycentricity from a geographical perspective. Geographical Analysis, 52(2), 169-189.

Smętkowski, M., Jałowiecki, B., \& Gorzelak, G. (2009). Obszary metropolitalne w Polsce - diagnoza i rekomendacje. Studia Regionalne i Lokalne, 35(1), 52-73.

Sobolevsky, S., Campari, R., Belyi, A., \& Ratti, C. (2014). General optimization technique for high-quality community detection in complex networks. Physical Review, E 90(1).

https://doi.org/10.1103/physreve.90.012811

Sohn, J. (2005). Are commuting patterns a good indicator of urban spatial structure? Journal of Transport Geography, 13(4), 306-317. https://doi.org/10.1016/j.jtrangeo.2004.07.005

Spórna, T. (2016). Policentryczność struktury przestrzennej miasta - przykład Sosnowca (praca doktorska), Uniwersytet Śląski w Katowicach.

Szabó, T., Szabó, B., \& Kovács, Z. (2014). Polycentric urban development in post-socialist context: the case of the Budapest Metropolitan Region. Hungarian Geographical Bulletin, 63(3), 287-301. https://doi.org/10.15201/hungeobull.63.3.4

Szajnowska-Wysocka, A. (1995). Podstawy zorganizowania miast konurbacji górnoślq̨skiej. Prace Naukowe Uniwersytetu Ślq̨skiego w Katowicach, 1470. Katowice: Wydawnictwo Uniwersytetu Śląskiego.

Śleszyński, P. (2013). Delimitacja Miejskich Obszarów Funkcjonalnych stolic województw. Przeglqd Geograficzny, 85(2), 173-197. https://doi.org/10.7163/przg.2013.2.2

Śleszyński, P. (2014). Delimitation and typology of functional urban regions in Poland based on commuting, 2006. Geographia Polonica, 87(2), 317-320. https://doi.org/10.7163/gpol.2014.20

Śleszyński, P. (2015). Problemy delimitacji miejskich obszarów funkcjonalnych w Polsce. Rozwój Regionalny i Polityka Regionalna, 29, 37-53. https://doi.org/10.14746/rrpr.2015.29.04

Śleszyński, P. (2018). Polska średnich miast: założenia i koncepcja deglomeracji w Polsce. Kraków: Klub Jagielloński.

Tammaru, T. (2005). Suburbanisation, employment change, and commuting in the Tallinn metropolitan area. Environment and Planning A, 37(9), 1669-1687. https://doi.org/10.1068/a37118

Taubenböck, H., Standfuß, I., Wurm, M., Krehl, A., \& Siedentop, S. (2017). Measuring morphological polycentricity. A comparative analysis of urban mass concentrations using remote sensing data. Computers, Environment and Urban Systems, 64, 42-56.

https://doi.org/10.1016/j.compenvurbsys.2017.01.005 
Thomas, R. (1973). The separation of home and workplace. W: P. Hall, H. Gracey, R. Drewett, \& R. Thomas (red.), The planning systems, objectives, operations, impacts. London: Allen and Unwin. https://doi.org/10.1007/978-1-4899-1210-7_2

Van der Laan, L. (1998). Changing urban systems: An empirical analysis at two spatial levels. Regional Studies, 32(3), 235-247. https://doi.org/10.1080/00343409850119733

Vasanen, A. (2012). Functional polycentricity: examining metropolitan spatial structure through the connectivity of urban sub-centres. Urban Studies, 49(16), 3627-3644. https://doi.org/10.1177/0042098012447000

Veneri, P. (2010). Urban polycentricity and the costs of commuting: Evidence from Italian metropolitan areas. Growth and Change, 41(3), 403-429. https://doi.org/10.1111/j.1468-2257.2010.00531.x

Waterhout, B. (2002). Polycentric Development - What's Behind It?. Nijmegen: University of Nijmegen, Nijmegen School of Management.

Wiśniewski, R. (2012). Codzienne dojazdy do pracy - metodyczne aspekty badania wielkości i struktury dojazdów na przykładzie Białegostoku. Studia Regionalne i Lokalne, 49(3), 50-64.

Wurster, C.B. (1963). The form and structure of the future urban complex. Cities and Space, Johns Hopkins UP, 73-102. https://doi.org/10.4324/9781351300520-3

Zhang, W., \& Derudder, B. (2019). How sensitive are measures of polycentricity to the choice of 'centres'? A methodological and empirical exploration. Urban Studies, 56(16), 3339-3357. https://doi.org/10.1177/0042098019843061

Zipf, G.K. (1949). Human behavior and the principle of least effort. Cambridge, Mass.: Addison-Wesley. Zuzańska-Żyśko, E. (2018). Polycentricity and commuting. An application to metropolitan areas in the south of Poland, Acta Geobalcanica, 42), 77-84.

\section{Summary}

Studies dealing with the issue of polycentric urban development, both functional and morphological, often promote different approaches to the measurement of polycentricity. Relying on data on commuting patterns and the intra-regional distribution of population in Poland in 2011, we apply two measures of polycentricity to shed more light on the functional and morphological development of urban regions in Poland. We also explore the relationship between the two dimensions of polycentricity, using a functional/morphological primacy index and a general functional polycentricity index. The results reveal regions for which the different measures suggest divergent conclusions, while also implying that the measure used can determine the strength and statistical significance of the relationship between the two dimensions to polycentricity. As, in our view, it is the measure advocated by Burger et al. (2011) that best seems to differentiate between the different forms of urban structure, we use this to summarise patterns of polycentric urban development in Poland. The results illustrate: the statistical significance of the relationship between the two (morphological and functional) dimensions to polycentricity in Poland's urban regions, and the way in which the level of functional polycentricity is higher than the degree of functional polycentricity. 